\title{
PROBLEMS CONNECTED WITH THE CREATION OF EURATOM*
}

\author{
Pierre Mathijsent
}

In the third annual report of the Commission of Euratom to the European Parliamentary Assembly, it was pointed out that "like the European Coal and Steel Community and the European Economic Community, the European Community for Atomic Energy finds its origin in the will of the Member States to build Europe."1 This statement is important because it defines the political and organizational framework of Euratom. When examining some of the problems related to the creation of Euratom, one must not forget that although this Community differs from the other two in its tasks, its field of action, and its powers, it must be seen in connection with them and as a means towards the political and economic integration of Europe.

Integration appears particularly urgent in the field of atomic energy. The development of a nuclear industry would be impossible if each country were to act separately and relied exclusively upon its own resources.

As is stated in the preamble to the Euratom Treaty, "nuclear energy constitutes the essential resource for ensuring the expansion and renovation of production and for progressing in peaceful achievements." Belgium, France, Germany, Italy, Luxembourg, and The Netherlands decided, therefore, to "create the conditions required for the development of a powerful nuclear industry which would provide extensive supplies of energy, lead to modernization of technical processes, and contribute in various other ways to the well-being of their peoples." To achieve these objectives, the European Community for Atomic Energy (Euratom) was established by a Treaty signed in Rome on March 25, 1957, by the same six countries that composed the European Coal and Steel Community (E.C.S.C.) and the European Economic Community (E.E.C.).

Euratom can be defined as a union of sovereign states, based upon an international treaty, with institutions of its own, acting independently from the Member States, endowed in the field of nuclear energy with powers not only within the Community, but also competent to act as an international legal person. ${ }^{2}$

There are four institutions: the Commission, the Council of Ministers (assisted

* This article only reflects the personal views of the author and may in no way be interpreted as expressing the opinion of an institution of the Community.

TLL.M. 195I, Dr. iur. 1957, University of Leyden (The Netherlands); M.A. 1952, University of Minnesota. Legal Adviser, European Atomic Energy Community, Brussels, Belgium. Author, Lz Drorr de la Communauté Européenne du Charbon et de l'Acter-une Etude des sources (x958).

${ }^{1}$ Euratom, Troisième Rapport Géneral sur l'activité de la Communauté 7 (1960) [hereinafter cited as TroisièMe Rapport GÉNÉrAL].

${ }^{2}$ The Community is, e.g., competent to conclude treaties with third countries, Euratom Treaty art. Ior; and to receive diplomatic envoys. Protocol on the Privileges and Immunities art. I6. 
by the Economic and Social Committee and by the Scientific and Technical Committee), the Court of Justice, and the Parliamentary Assembly. The Commission is the central executive body upon which rests the task to implement the provisions of the Treaty. The Council of Ministers is composed of representatives of the governments of the Member States. These two institutions jointly exercise the legislative power of the Community; they are empowered to issue regulations, directives, and decisions that are directly binding not only upon the Member States, but also upon the persons and enterprises that fall within the jurisdiction of the Community. ${ }^{3}$ This legislative activity of the Commission and the Council is submitted to the judicial control of the Court of Justice: appeals for annulment may, as a rule, be brought before the Court against all binding legal acts of these institutions. Moreover, an annual report on the activities of the Community is submitted for discussion to the Assembly. This last body can, by adopting a motion of censure, express disagreement with the way in which the Commission carried out its task and thus force the members of this Commission to resign their office.

What Lauterpacht has said about the E.C.S.C. also applies to the legal structure of Euratom: "[I]t exhibits in some respects distinct features of the federal system." A more detailed description of the Community's structure and of its regulatory responsibilities will not be attempted here. ${ }^{5}$ The present contribution intends to examine some of the legal, economic, political, and social problems that have arisen for the Community in the various fields in which powers were conferred upon it-namely, nuclear research, dissemination of information, health protection, industrial development, safety control, supply of nuclear materials, and international relations.

\section{I}

\section{RESEARCH AND INFORMATION}

The task of Euratom in the field of nuclear research is two-fold: (I) coordination of the national research programs of the Member States and, eventually, their completion through direct or indirect financial assistance, through supply of material, or by making available facilities, equipment, and expert assistance; and (2) carrying out of the Community's own research program. The means put at the disposal of Euratom in order to achieve these two aims are numerous.

The most intricate of these tasks is the coordination of the national programs. No direct legal means have been put at the disposal of Euratom to enforce its views

\footnotetext{
${ }^{3}$ According to Euratom Treaty art. 196, these persons and enterprises are natural persons, enterprises, or institutions, whatever their public or private legal status, which are wholly or partly engaged in the territories of the Member States in activities that come within the field defined by the approprate chapter of the Treaty.

t I H. Lauterpacht, Oppenheim's International LaW i87 (1958).

"For such a description, see, e.g., Vogelaar, Euratom: Its Relations to the Other European Communities and Its Regulatory Responsibilities, in Federal Bar Ass'n, INSTITUTE on Legal Aspects OF THE EUROPEAN Community I88 (1960); Gaudet, Euratom, Progress in Nuclear Energy, in Herbert S. Marks (Ed.), LAW AND ADMINISTRATION I40 (1959).
} 
in this domain, and much depends on the goodwill of the Member States. However, as the individual members are not always in a position, essentially through lack of funds, to complete their programs, they need assistance from the Community, which consequently reinforces Euratom's position.

As for the execution of its own research program, Euratom may act in various ways. The programs themselves, except for the first five-year program, which is laid down in an Annex to the Euratom Treaty, will be drawn up periodically by the Council of Ministers.

In principle, these programs must be implemented in the Joint Nuclear Research Center of the Community, which the Commission is to establish. For this, the Commission had to choose between either constructing its own center or taking over already-existing national research facilities. Legally, the Commission was free to choose either solution; technically and scientifically, however, it was not justified in building a new research center when, in the Member States, so many installations were standing idle or unfinished. Politically, it was essential for the Community to assert itself as rapidly as possible in this important field. The Commission decided, therefore, to take over the existing facilities of Ispra in northern Italy. The agreement signed .in July I959 between Euratom and the Italian Government, concerning the transfer of this center to Euratom was ratified by the Italian Parliament at the end of July 1960 .

This delay in the ratification procedure constituted a serious handicap for the research activity of the Community. It is also a typical example of the kind of problems encountered by Euratom. Although the Commission has been endowed with the necessary legal authority and financial means, the implementation of this particular task was delayed by circumstances beyond its control. This is also true for the installations of the Joint Nuclear Research Center that the Commission has created in Karlsruhe (Germany), and intends to establish in Petten (The Netherlands), and Mol (Belgium).

It is fortunate, however, that the joint research center is not the only means put at the disposal of the Community for the execution of its own research program. Article ten of the Euratom Treaty provides that "the Commission may, by means of contracts, entrust Member States, persons or enterprises, or also third countries or international organizations or nationals of third countries with the implementation of the Community's research program."

During the $2 \frac{1}{2}$ years of its existence, Euratom has mainly depended upon such contracts for its research work. This system proved not only satisfactory for the Community, but also useful for European research institutions. Most of these contracts were concluded with persons and enterprises within the Community, but Euratom also participates in two important projects in third countries-namely, the Halden Boiling Water Reactor Project in Norway and the High Temperature GasCooled Reactor Project (Dragon) in Great Britain.

It was within the framework of the Euratom-United States Agreement for 
Cooperation $^{6}$ that a vigorous impetus was given to this means of research. The interest of private and public organizations in this joint program is clearly demonstrated by the fact that more than 400 proposals were submitted to the Joint Euratom/United States Research and Development Board that was created shortly after the signing of the Agreement in 1958 . The various research organizations within the Community were particularly eager to become acquainted with nuclear technology, and for most of them, the financial contribution of Euratom was very welcome.

As for the information resulting from the execution of these research contracts that are financed by the contributions of the Member States, it is obvious that it must be at the disposal of the latter and of the persons and enterprises within the Community. This principle is laid down in articles twelve and thirteen of the Euratom Treaty and applies not only to information acquired through research contracts, but also to information obtained by virtue of international agreements or acquired in the Joint Nuclear Research Center of the Community. While the dissemination of information obtained from the last two sources does not create any major difficulty, because this information is, generally speaking, at the disposal of the Community, the research contracts present the Commission with serious problems.

Although the enterprises and research organizations within the Community are eager to participate in the implementation of Euratom's research program, they are of the opinion that they should obtain certain exclusive rights with regard to information, and especially patentable information. In their opinion, payment of the direct costs does not counterbalance the contribution of the enterprise under a research contract.

The Commission, however, believes that in order to fulfill its obligations with regard to dissemination of information, it must, whenever possible, obtain the fullest rights to communicate information and to grant licenses or sublicenses on the patented results of its research contracts. (Euratom Treaty article twelve). A distinction was, however, made between the nuclear and the nonnuclear applications of such patents and it thus became possible for the Commission, while respecting the provisions of the Treaty, to grant some exclusive rights to Euratom's contractors by conceding to them the patent rights for the nonnuclear applications of their invention. Another solution was to permit the contractor to obtain certain exclusive rights with regards to patent rights outside the Community. But it would be contrary to the Treaty to accept that licenses or sublicenses to exploit patents resulting from Euratom's research contracts may only be granted with the consent of the inventor.

The position of the Commission in this field is strongly reinforced by the extensive powers that have been provided for in chapter two of the Euratom Treaty. Not only are the Member States obliged to communicate to the Commission, at its

'Agreement with the European Atomic Energy Community, Aug. 27, 1958, [1958] 9 U.S.T. \& O.I.A. III6, T.I.A.S. No. 4091 
request, the contents of applications for patents relating to a specifically nuclear field and patents that appear prima facie to them to deal with a subject that, without being of a specifically nuclear nature, is directly connected with and essential to the development of nuclear energy; but the Community is also empowered to have nonexclusive licenses granted, ex officio, either to the Community or to persons or enterprises. This right to expropriate industrial property is one of the most extensive powers provided for in the Treaty. It also proves that dissemination of information has been considered by the drafters of the Treaty as essential to the public interest, this last aspect being the generally admitted ground for expropriation in municipal law.

It should be noted that the powers of the Commission in this field are in no way arbitrary; the procedure provided for in the Euratom Treaty constitutes a sufficient guarantee for every patent-holder within the Community that his rights, and particularly his right to compensation, will be respected. A special arbitration committee is provided, which can settle all such questions, while appeal to the Court of Justice of the European Communities is always possible. Finally, article eighteen of the Treaty explicitly states that the provisions regarding expropriation "shall not affect the provisions of the Paris Convention for the protection of industrial property."

The problems raised by the Euratom Treaty provisions concerning patents and dissemination of information have an important social aspect as well. The rights of the individual inventor must be protected. According to the municipal law of the Member States, ${ }^{7}$ the inventor is basically the owner of his invention, but the law concedes to the employer of the inventor a right to claim the invention, which can only be done against payment of a special compensation, the amount of which depends on the industrial importance of the invention.

The Commission, therefore, states in its third annual report ${ }^{8}$ that "certain principles of its policy which are already applied in its research contracts will establish a fair equilibrium between the interests of the Community, of the inventors and of the enterprises."

\section{II}

\section{Health Protection}

Article two of the Euratom Treaty provides that the Community shall "establish and enforce the application of uniform safety standards to protect the health of workers and of the general public." Article thirty further specifies this obligation by providing for the establishment within the Community of "basic standards"-i.e., (I) the maximum doses of ionizing radiations compatible with adequate safety, (2) the maximum permissible degree of exposure and contamination, and (3) the

${ }^{7}$ See, e.g., German law: Gesetz über Arbeitnehmererfindungen of July 27, 1957, [1957] I Bundesgestzblatt 756; Richtlinien für die Vergütung von Arbeitnehmererfindungen im privaten Dienst of July 20, I959.

8 Troisième RApport Général 39. 
fundamental principles governing the medical supervision of workers. However, in matters of health protection, the major responsibility lies with Member States, and according to article thirty-three of the Euratom Treaty "each Member State must enact the legislative and administrative provisions required to ensure compliance with the basic standards." In I959 the Community issued directives concerning the basic standards; ${ }^{9}$ directives, according to article $16 \mathrm{I}$ of the Treaty, "bind any Member State to which they are addressed as to the results to be achieved, while leaving to domestic agencies a competence as to the form and means." The directives issued by Euratom constitute the first step towards the establishment of uniform safety standards enforceable in several countries.

Important from a legal point of view is the word "uniform." It is not clear whether it qualifies only the basic standards established by the Community or also the national provisions that are necessary for the application of the basic standards within the Member States. It must be noted in this respect that no direct powers were conferred upon the Community to achieve uniformity. The Commission can only make recommendations ${ }^{10}$ in order to ensure the harmonization of the provisions applicable in the Member States.

More important than the powers of the Community are the principles that were laid down and that are now binding upon all Member States. An exhaustive review of this important example of international legislation in the field of health protection will not be made here, but it might be useful to point out a few of the basic principles.

By virtue of the basic standards, all production, treatment, handling, utilization, possession, stocking, transportation, and elimination of natural or artificial radioactive elements must be communicated to the national authorities and eventually submitted for prior authorization. Another essential principle is that a prior authorization must always be required for ( $I$ ) the use of radioactive elements for medical purposes; (2) the addition of radioactive elements to food, medicaments, cosmetics, and household products; and (3) the use of radioactive elements in the fabrication of toys.

The social importance and implications of these principles are so great that no major obstacles were encountered by the Commission in the drafting of the directives, but it is surprising that as of June Ig6I, only one country-namely, Germanyhas enacted the legislative and administrative provisions required to ensure compliance with the basic standards. And although Belgium, Italy, Luxembourg, and The Netherlands have communicated drafts of provisions to the Commission, the fact remains that, as the Commission stated it explicitly, "one year after the publication of the Basic Standards the situation is not satisfactory."11 "The Community, however, is not a powerless witness, and if a Member State were to refuse to enact the neces-

\footnotetext{
- [i959] Journal Officiel de la Communauté Europénne du Charbon et de l'Acier [́hereinafter cited as Journal OFFiciel].

${ }^{10}$ Euratom Treaty art. $16 \mathrm{r}$; recommendations have no binding force.

11 Troisiz̀me Rapport Général 77.
} 
sary provisions, the Commission could consider an appeal to the Court of Justice based on article I4I of the Euratom Treaty. ${ }^{12}$

Although the Community does not, as was pointed out, possess the authority to enact directly binding provisions in the field of health protection, it possesses a sort of indirect legislative power to fulfill an important social task.

\section{III}

Industrial DeVelopment

The Community is to achieve its aim by "the creation of conditions necessary for the speedy establishment and growth of nuclear industries." ment is, therefore, the first objective of Euratom. In the Treaty establishing the Community, three chapters contain provisions more directly connected with this objective. They endow the Community with certain powers in the field of investment, make possible the creation of joint enterprises, and provide for the establishment of a nuclear common market.

As all the Member States adhere, officially at least, to the principle of free enterprise, very little authority was given to the Community in investment matters. The role of the Commission is purely advisory; it must periodically publish programs indicating in particular the production targets for nuclear energy, ${ }^{14}$ and investment projects must be communicated ${ }^{15}$ for discussion and advice to the Commission.

This may seem very meager, and, from a purely legal standpoint, it is, indeed; but in reality, the opinion given by the Commission-and which is communicated to the Member State concerned-carries much weight. This was clearly proved by the practice of the E.C.S.C., where the High Authority has similar powers. ${ }^{10}$ It appears that the opinion of that Authority is a decisive factor when enterprises seek to obtain bank loans in order to finance their investment. One enterprise even appealed to the Court of Justice for annulment of such an opinion, arguing that it had caused a certain prejudice to the enterprises. The Court declared the appeal inadmissible. ${ }^{17}$

According to article forty-six of the Euratom Treaty, industrial undertakings of special importance to the development of the nuclear industry in the Community may be established as joint enterprises. By joint enterprise is meant an enterprise established by a decision of the Council. The Community itself may participate in the financing, and participation by third countries is also possible. Although these

\footnotetext{
12 "If the Commission considers that a Member State has failed to fulfill one of its obligations under this Treaty, it shall give a reasoned opinion on the matter after requiring such State to submit its comments. If such State does not comply with the terms of such opinion within the period laid down by the Commission, the latter may refer the matter to the Court of Justice."

${ }^{18}$ Euratom Treaty art. $r$.

14 Troistème Rapport GENERal 42-55. 185.

${ }^{15}$ Regulation No. 4, [1958] Journal Officiel 4I7; Regulation No. 5, [1959] Journal Ofpiciel.

${ }^{10}$ E.C.S.C. Treaty art. 54 .

17 ReCueil DE LA JURisprudence de LA COUR 205 (I957).
} 
enterprises are subject to the municipal rules applying to industrial or commercial undertakings, the Council may declare applicable to the joint enterprise certain advantages like exemption from all direct taxation or from all custom duties. Up to this time, only one such enterprise has been created by the Council.

Of great economic importance for the development of nuclear industries is the establishment of the nuclear common market. Chapter nine of the Euratom Treaty provides, among other things, for (I) the establishment of a free trade area ${ }^{18}$ among the Member States-i.e., abolition of all import and export duties or charges and all quantitative restrictions on imports or exports with respect to a number of products enumerated in an annex to the Treaty; (2) the creation of a customs union ${ }^{10}$-i.e., establishment of a common customs tariff; (3) the abolition of restrictions placed upon access to specialized employment in the nuclear field by nationals of the Member States; (4) the abolition of restrictions based on nationality, which might be applied to natural or legal persons wishing to participate in the construction of nuclear facilities; and, finally, (5) the free movement of capital destined for nuclear industries.

The establishment of the free trade area and the customs union raised a certain number of legal problems. In the first place, the question was asked whether these economic measures were compatible with the provisions of the General Agreement for Tariffs and Trade (G.A.T.T.). The free trade area and the customs union being limited to nuclear products, there might seem to be an incompatibility with said Agreement. It has been argued, however, that the nuclear common market is but a forerunner of the general Common Market established by the E.E.C., which is, indeed, compatible with the G.A.T.T.-the only difference being that the general Common Market is being established progressively, while the nuclear common market came into being on January I, I959.

But, if one accepts this last thesis, one may wonder whether the nuclear common market should not coincide geographically with the general Common Market. It should be noted that, according to the E.E.C. Treaty, ${ }^{20}$ the Common Market applies to the European territories of the Member States and to Algeria and the French overseas departments, while the provisions of the Euratom Treaty apply "except when otherwise provided . . . to the European territories of the Member States and to non-European territories subject to their jurisdiction," ${ }^{21}$ which covers a much larger area. There is, of course, an answer to this objection: although the Euratom Treaty nowhere states that the nuclear common market is but a part of the general Common Market, this is implied, with the consequence that the E.E.C. territorial provisions also apply to the nuclear common market, thus constituting an exception in the sense of article I98: "except when otherwise provided." 93(a).

${ }^{18}$ Agreement signed in Brussels by the Member States on Dec. 22, 1958, based on Euratom Treaty art. (a). art. 94 .

Agreement signed in Brussels by the Member States on Dec. 22, 1958, based on Euratom Treatv

${ }^{20}$ E.E.C. Treaty art. 227.

${ }^{21}$ Euratom Treaty art. 198. 
These are but a few of the many questions that arise with the implementation of the nuclear common market; but when one considers the advantages that it entails for the industrial development within the Community, the struggle to solve these problems seems, indeed, worthwhile. A single example may illustrate this: The common customs tariff that was established for nuclear products (i.e., the tariffs applicable to products imported from third countries to the Community) provides for the following duties: $:^{22}$ fissionable and nuclear materials and radioactive isotopes are completely free from duties; the duty of ten per cent on nuclear reactors is suspended until January I, I962; and the duties of five to twelve per cent on the other nuclear products have been partly or completely suspended until January 1, 1964. At the present time, nuclear products circulate practically freely not only within the Community, but also between the Community and third countries.

\section{IV}

\section{Responstbility and Nuclear Insurance}

Before discussing the powers and activities of the Community in matters of security control, supply, and external relations, some remarks must be made about a problem that has far-reaching social and legal implications: the responsibility for nuclear accidents and the insurance of the risks involved.

Article ninety-eight of the Euratom Treaty provides that "the Member States shall take all necessary measures to facilitate the conclusion of insurance contracts covering atomic risks." It further enjoins the Council, acting on proposal of the Commission and after consultation of the Assembly and of the Economic and Social Committee, to issue directives as to the particulars of application of said Article.

At the present time, in the absence of the necessary legislation, insurance of atomic risks can only be obtained either up to a limited amount or at prohibitive prices. While countries like the United States have enacted provisions establishing the amounts for which the operator of a nuclear installation is responsible and, consequently, required to take insurance, and, furthermore, providing for state responsibility for damages exceeding this amount, on the Continent, private enterprises cannot insure a risk that is in no way foreseeable or limited. But as all nuclear installations in Europe were, until recently, state-owned and the risks, therefore, covered by a state responsibility, the problem was not too urgent. The establishment of Euratom, the aim of which was precisely the development of nuclear industries, however, made the solution of this problem indispensable.

The present situation is, indeed, most unsatisfactory and socially unacceptableunsatisfactory because private enterprise is seriously handicapped in its efforts toward rapid development, and unacceptable because the eventual victims of a nuclear mishap might be deprived of adequate compensation in the absence of state guarantee or sufficient coverage. As the Commission pointed out, ${ }^{23}$ the geographical

${ }^{29}$ Troistìme Rapport GÉntraI 59.

${ }^{28} \mathrm{Id}$. at $6 \mathrm{r}$. 
situation of Europe is such that a nuclear accident can cause damage beyond the borders of the country where the accident occurs. It is, therefore, necessary that all. the eventual victims receive compensation according to identical principles and without discrimination based on nationality.

The solution envisaged to resolve these various problems is an international convention. Nearly three years ago, negotiations were initiated within the Organization for European Economic Cooperation (O.E.E.C.), but the task of defining principles acceptable to the eighteen member countries appears to be extremely difficult. Furthermore, the resulting convention will not cover the whole field, and, therefore, the Member States of Euratom have already foreseen and drafted an additional convention that will be open to all countries and will supplement the provisions of the O.E.E.C. Convention.

The principles of the O.E.E.C. Convention are as follows:

I. The operator of a nuclear installation is, irrespective of his fault, responsible for all damages caused by his installation; this is the so-called "objective responsibility."

2. The operator alone is responsible for damages caused to third parties.

3. The responsibility is limited to \$I5 million; however, this amount may bereduced to $\$ 5$ million.

4. Appeals against the operator must be filed within a ten-year period.

As can be noted, the convention does not provide for legal responsibility beyond: a certain amount; this amount, furthermore, must be considered as insufficient. Theadditional convention referred to above would, therefore, establish a second "layer" of state responsibility of between $\$ 15$ million and $\$ 50$ million, and a third one up to. $\$ r o o$ million. The latter would be covered jointly by all the signatories of the additional convention.

It is not an exaggeration to state that the development of nuclear industry depends in great part upon the solution of this problem. It is, therefore, alarming to ascertain that little progress has been made in this field since negotiations were initiated fouryears ago.

\section{V}

\section{Safety Control and Property Rights}

These two subjects are examined together because the Community's right of ownership is limited to the special nuclear materials that are subject to Euratom's. control. $^{24}$ This control has a threefold purpose; the Commission must determine that in the Member States ( $I$ ) ores and materials are not diverted from the destination for which they were intended, (2) the provisions concerning supply are ob-served, and (3) special undertakings entered into by the Community in international agreements are respected. It can, therefore, be said that Euratom's control is mainly*

\footnotetext{
${ }^{24}$ Euratom Treaty art. 86.
} 
a "conformity-control"-i.e., conformity of the use with declared destination and with the Treaty provisions regarding supply.

The control-system of Euratom has characteristics that differentiate it from other existing systems. In the first place, it is actually the only working system that applies to more than one country. Secondly, it is compulsory for all the Member States and applies automatically to all ores, source materials, and special nuclear materials-the control of the International Atomic Energy Agency in Vienna and of the O.E.E.C. only applies to materials and equipment received through these organizations or to countries that voluntarily submit to their control. Finally, Euratom's control is not solely intended to prevent materials from being used for nonpeaceful purposes, but also to enforce the provisions concerning supplies.

Euratom's control is based on information, which is obtained through the compulsory communications to the Commission ${ }^{25}$ and by inspection, which the Commission is empowered to carry out in all installations within the Community. ${ }^{20}$

It is important to note that the United States, ${ }^{27}$ Great Britain, ${ }^{28}$ and Canada ${ }^{20}$ have formally recognized Euratom's control system by admitting that, as an exception to their usual policy, the materials and equipment supplied by them will be subject to the sole control of Euratom.

The Commission was endowed with large powers in order to ensure compliance with the control measures. The Euratom Treaty provides the Community with the authority to impose directly binding sanctions on any person or enterprise, private or public, that does not fulfill its obligation. The penalties that can be imposed by the Commission range from a simple warning to the complete withdrawal of source materials or special nuclear materials. ${ }^{30}$ Decisions of the Commission concerning withdrawal of materials may be enforced within the territories of the Member States in accordance with the provisions of article 164 of the Treaty. After verification of the authenticity of the Commission's writ of execution by a national authority, the Commission may, in accordance with municipal law, proceed with forced execution by applying directly to the competent national bodies.

Euratom's control system became effective in June 1959; as of that date, installations within the Community report each month to the Commission on the stocks and movements of materials. Moreover, the first inspections were carried out at the beginning of 1960 . The only limitation imposed on the implementation of the security control-see article eighty-four of the Euratom Treaty-results from the fact that control may not cover materials intended for "the purposes of defense which

${ }^{25}$ Regulations No. 7 and No. 8, [1959] Journal OFFiciel 298, 651, based respectively on articles 73 and 79 of the Euratom Treaty.

${ }^{20}$ Euratom Treaty art. 8r.

${ }^{27}$ Agreement of Cooperation Between the Government of the United States of America and the European Atomic Energy Community (Euratom) Concerning Peaceful Uses of Atomic Energy, Nov. 8, 1958, art. XII, [1959] Journal Officiel 312, [1958] 9 U.S.T. \& O.I.A. 1116, T.I.A.S. No. 4091.

${ }_{28}$ Agreement Between the United Kingdom and Euratom, Feb. 4, 1959, art. XIII, \& 2, [1959] JournaL Officier 33t.

${ }^{29}$ Agreement Between Canada and Euratom, Oct. 6, 1959, art. IX, [1959] Jouknal Orficiel, Ir69.

${ }^{30}$ Euratom Treaty art. 83. 
are in the course of being specially prepared for such purposes or which, after being so prepared, are, in accordance with an operational plan, installed or stocked in a military establishment."

This limitation of the Community's control brings us back to an earlier statement-namely, that Euratom's property rights end with its power to control. What, exactly, are these property rights?

Although article eighty-six of the Euratom Treaty states that "special nuclear material shall be the property of the Community," article eighty-seven qualifies this statement by adding that "Member States, persons or enterprises shall have the widest rights of use and consumption of special nuclear materials legally in their possession, subject to their obligations resulting from the provisions of this Treaty ...." One might wonder, therefore, what the meaning is of the Community's property right, when all the attributes of property belong to others. Politically, this right finds its explanation in the fact that private ownership of nuclear material seemed unacceptable at the time of the drafting of the Treaty. Furthermore, in all other countries, even in the United States, special nuclear materials are, in fact, the property of the government.

It is difficult to determine with precision what rights result for the Community from its ownership. The most important consequence is obviously that holders cannot alienate materials belonging to Euratom; and in case of unauthorized transfer outside the Community, Euratom could reclaim these materials on the ground of its ownership. In this regard, ownership reinforces Euratom's legal monopoly in the sale of special nuclear material. Another consequence is that these materials may not be the subject of any administrative or legal measure of constraint without the authorization of the Court of Justice. ${ }^{31}$

Euratom's right of property cannot be compared without qualifications with the right of property recognized by civil law. Articles eighty-eight and eighty-nine of the Euratom Treaty provide that the Supply Agency shall keep, on behalf of the Community, a so-called "Financial Account of Special Nuclear Materials" in which the value of materials put at the disposal of Member States, persons, or enterprises is credited to the Community and debited to that Member State, person, or enterprise, and where produced or imported materials that become Euratom's property are debited to the Community and credited to the producer or importer. Upon the request of the creditor, balances shall be payable immediately. It may, therefore, be said that the Community's property rights are, essentially, of an administrative nature.

One important conclusion is that Euratom's property rights are not incompatible with the ownership of a third party over the same materials. It was first thought that the wording of article eighty-six of the Euratom Treaty ("special nuclear materials shall be the property of the Community") prevented Euratom from importing materials on a lease basis, as the rights of ownership of the lessor would be

\footnotetext{
${ }^{32}$ Protocol on the Privileges and Immunities, art. $x$.
} 
an obstacle to the Community's acquiring property rights. The Community would, therefore, be forced to purchase. The financial consequences of such a situation would have been disadvantageous, as, at the present time, purchase entails heavier expenditures than lease. One must admit that such a consequence could not have been intended by the drafters of the Treaty, and the theory of administrative ownership compatible with property rights of a third party appears as a legal and economically satisfactory solution.

\section{VI}

SuPPLY

One of the most important tasks entrusted to the Community is to "ensure a regular and equitable supply of ores and nuclear fuels to all users in the Community."32

The Euratom Treaty provides that (I) all practices designed to ensure a privileged position for certain users shall be prohibited; and (2) that an Agency shall be constituted having (a) an option right on all ores and materials produced within the Community and (b) the exclusive right to conclude contracts pertaining to the supply of ores and materials, whatever their origin. The Statutes of the Agency were laid down by the Council in July $1958{ }^{33}$ and the Agency assumed its functions on June $\mathrm{I}, \mathrm{I} 960^{34}$ The Commission decided, however, to suspend the authority of the Agency with regard to ores and source material until December $\mathrm{x}$, 1960 . $U_{p}$ to that moment, the conclusion or renewal of agreements for the supply of ores, source materials, and special fissionable materials needed the prior approval of the Commission. ${ }^{35}$ Since that date the Agency exercises its exclusive right to conclude all supply contracts, with the exception of ores and source material over which the Agency had no authority prior to December $x, 1960$.

Thus, at the present time, all supply contracts must be concluded by the Agency. Does this mean that the Agency necessarily becomes a party to such contracts? This would involve unnecessary delays; furthermore, formal contracts are not concluded for each transfer. Therefore the following system was set up by the Commission: In case of overproduction of a certain product-as is the case for practically all products-the Agency will lay down general conditions that will apply to all contracts; these contracts are then negotiated directly between the producer and the consumer and communicated to the Agency. If the Agency formulates no objections within a time limit of eight days, the contract is considered to have been "concluded by the Agency."36

This system, which is certainly in conformity with the spirit of the Euratom Treaty, simplifies the procedures imposed upon the consumer, and at the same time

\footnotetext{
${ }^{32}$ Euratom Treaty art. 2(d).

s3 [1958] Journal OFFICIEL 534.

34 [1960] id. at 776.

s5 Euratom Treaty art. 222.

3e Regulations of the Agency art. 5, [1960] Journal Officiel 778.
} 
gives the Agency all the information it needs to accomplish its task-i.e., to follow the evolution of the general market situation, the fluctuation of prices, and the conditions prevailing for transactions involving nuclear materials. This information is essential if the Agency wants to improve the supply situation of the Community.

\section{VII}

\section{External Relations of the Community}

One of the tasks of the Community is to "establish with other countries and with international organizations all contacts likely to promote progress in the peaceful uses of nuclear energy."37

Articles ror and ro2 of the Euratom Treaty establish the principle that the Community may enter into obligations by concluding agreements with third countries, international organizations, or nationals of third countries (external competence of the Community); they also provide internal rules of procedure for the conclusion of such agreements.

Articles I03 and ro4 of the Euratom Treaty impose certain obligations on Member States and enterprises that conclude agreements with third parties that in some way or other concern the field of application of the Treaty. Member States must submit the draft of the agreement to the Commission, which can raise objections in case the agreement contains clauses impeding the application of the Treaty. Member States may not conclude the agreement before the objections have been removed. Persons and enterprises, on the other hand, may not invoke such agreements to evade obligations imposed by the Treaty. There are two exceptions to this procedure.

I. When the purpose of the agreement is the exchange of scientific or industrial information $^{38}$ and requires on either side the signature of a State exercising its sovereignty, the agreement must be concluded by the Commission, which, however, can also authorize the Member State, person or enterprise to conclude it directly.

2. When the agreement contains provisions relating to the delivery of products coming within the authority of the Agency, the prior consent of the Commission is required. ${ }^{30}$

Articles 105 and 106 of the Euratom Treaty contain provisions regarding agreements with third countries entered into by Member States, persons, or enterprises, their nationals and international organizations, before the entry into force of the Treaty (January I, I958). Article I05 restates a general principal of law-namely, that existing rights and obligations resulting from an agreement cannot be voided by a subsequent convention. Article 106 provides that these rights and obligations must be assumed by the Community as far as possible.

This over-all picture reveals a coherent system according to which the Community has the exclusive right to establish with third countries all contacts likely

\footnotetext{
${ }^{87}$ Euratom Treaty art. 2.

${ }^{38}$ Id. art. 29.

${ }^{30}$ Id. art. 73 .
} 
to promote progress in the peaceful uses of nuclear energy. In matters of international cooperation in the nuclear field, the Member States have joined their forces in order to present a united and, therefore, stronger front in negotiation with third countries.

As, on the other hand, large powers were conferred upon the Community, the logical consequence is that the Member States are not only to abstain from establishing further direct contacts in matters that concern the application of the Euratom Treaty, but they must discontinue the existing contacts by transferring to the Community the rights and obligations resulting from their bilateral arrangements. This last obligation is clearly stated in article 106 of the Treaty. And what would be the meaning of such a transfer, if Member States were later to conclude new nuclear agreements? The underlying philosophy of chapter ten of the Treaty seems clear: All existing bilateral agreements between the Member States and third countries are to be transferred to the Community, which becomes the exclusive channel for all the external relations of the Community in the field of peaceful uses of atomic energy. However, a strict separation between nuclear and other questions is not always possible; and as the creation of Euratom does not affect the external relations of Member States in general, the flexible procedure provided for by article ro3 respects both the rights of Euratom and the sovereignty of the Member States.

As for the agreements with the principal nuclear powers of the western world, which were mentioned above, they were concluded on the basis of the provisions of article ror of the Treaty.

Of particular importance is the agreement for cooperation between the United States of America and the Community, which provides for a joint reactor program and a joint research and development program. The purpose of the first program is to bring into operation within the Community large-scale power plants using nuclear reactors of types that have reached an advanced stage of development in the United States, having a total capacity of approximately one million kilowatts of electricity under conditions that would approach the competitive range of conventional energy costs in Europe. Partly because the premises on which the agreement was based-shortage of conventional fuels-have changed and also because some of the conditions imposed on participating facilities did not appear attractive enough, only one reactor, instead of the expected five, will be in operation by December 31,1963 , while there are reasonable expectations for two more to be in operation by the end of 1965 . The research and development program, which met with great successes, was discussed above.

The agreements concluded with Great Britain, with the Government of Canada and with the Atomic Energy of Canada, Ltd., provide the legal bases for further international cooperation in the peaceful uses of atomic energy.

Other contacts were established with international organizations such as the O.E.E.C., the Council of Europe, the International Agency for Atomic Energy (I.A.A.E.) and the International Labor Organization (I.L.O.). Furthermore, several 
third countries $^{40}$ have sent diplomatic representations to the Community, which through all these contacts participates in the international cooperation in the field of peaceful uses of atomic energy.

\section{Conclusion}

As was said in the beginning, Euratom cannot be examined separately from the E.E.C. and the E.C.S.C. Together they constitute the joint effort of the European countries to transform the face of the old continent. This close union created by the establishment of the three European Regional Communities is indispensable for a common economic policy. It is true that-as was seen for Euratom-this construction creates many problems, but it makes it possible to find solutions to economic and other difficulties that are beyond the capacities of the Member States when acting by themselves.

Many problems remain to be solved; as the Commission states: "[i]f some real progress was made, it is too limited, it is too slow, compared to the task imposed upon the Community." ${ }^{\prime 1}$ Nevertheless, Euratom is fulfilling its task by stimulating the development of nuclear industry and contributing to the economic and political unification of Europe. This double achievement constitutes an important contribution to the maintenance and development of world peace.

${ }^{10}$ In chronological order: United States of America, United Kingdom, Israel, Norway, Sweden, Denmark, Switzerland, Austria, Canada, and Japan. By virtue of the Protocol on the Privileges and Immunities art. 16 , these missions have been granted the customary diplomatic immunities.

${ }^{11}$ Trotsième Rapport GENERAL 7 . 